\title{
Recovering from a Natural Disaster: The Poster Project in the City of Onagawa, Japan
}

\author{
Shoji Azuma \\ Department of World Languages and Cultures \\ University of Utah \\ Salt Lake City, Utah 84112, USA
}

\begin{abstract}
Journalistic objectivity is the ideal that reporting should be based purely on facts without allowing a journalists' personal values, beliefs, and emotions into a story. However, in today's changing media environment, the principle of objectivity continues to be questioned. The present study examines the objectivity of local journalistsimmediately following the Eastern Japan Great Earthquake. In particular, we discuss the Kahoku Shin popposter project in the city of Onagawa, where extensive earthquake damage occurred. One of the findings is that, in a departure from objectivity, journalistic compassion is a great tool for connecting with the local community and forassisting with the recovery effort in the area.
\end{abstract}

Keywords: compassion, earthquake, empathy, poster, Japan

\section{Introduction}

On March 11, 2011, Japan was hit by a 9.0 magnitude earthquake commonly known as "the Eastern Japan Great Earthquake." It was the most powerful earthquake to have hit Japan in 140 years and one of the four most powerful earthquakesin the world since 1900(when record keeping began). The earthquake,and the powerful tsunami waves it triggered,claimed more than 19,000 lives, with thousands still missing. In addition, the earthquake caused meltdowns at three reactors in the Fukushima Daiichi Nuclear Power Plant. Even six years after the quake, nearly 120,000 people were displaced from their homes, including residents from Fukushima prefecture due to radioactive contamination in the region (Fukkōchō 2017).

How do survivors of natural disasters overcome such dire consequences? How do they deal with the panic, fear, sorrow, hopelessness, depression and emotional damage? How do they cope when they are frightened, desperate, and bitterly disappointed in their government's inadequate response to their destitute circumstances? While the answers to these questions may be wide and varied, for purposes of this inquiry, we will explore how journalists might contribute to assist the survivors, residents, and the community to overcome the crisis? What is the role of journalism ata time of disaster?The victims obviously need food, water, and other basic resources, but they also need positive, compassionate, emotional support to help them get through the hardship.

One scholar, Pinker (2018), who works in the area of cognition, language and social relations, has an interesting viewpoint. He argues that the people of the earth are in a stage of enlightenment where reason and sympathy can be used to enhance and encourage the flourishing of humankind. He suggests that the ideals of reason, science, humanism, and progress require a strong defense and he defends such ideals relying on a vast amount of accumulated data from all over the world. He pulls from a wide array of data in areas such as life expectancy, world income distribution, sustainability, population growth, terrorism deaths, literacy, leisure time, cost of air travel, suicide and global wellbeing, among others. In each case, Pinker (2018) sees progressover an extended period of time around the world.In particular, he arguesthat the data regarding natural disaster deaths between 1900 and 2015 show amazing progress. Over such period,he findsa drastic decrease of deaths. For example, in 1920-29,deaths per 100,000 people per year were about 28. However, over the years the number of deaths has amazingly decreased to about 2 deaths per 100,000 people per year, in 2010-15. His graph from the Our World in Data (Roser 2016) plots the sum of the death rates for drought, earthquake, extreme temperature and flood among others. In sum, Pinker (2018) argues that progress can clearly be shown, in relative terms, by the almost disappearance of the number of deaths due to natural disasters in the world. While it is not clear how the Japanese disaster may affect the trend, the overall decreasein deaths appears to be occurring on a global scale. In other words, natural disastersappear to be causing a fewer number of deaths when we consider the world as a whole. Pinker (2018: 188-189) states that "the good news is that as poorer countries get richer, they get safer (at least as long as economic development outpaces climate change.)."

Pinker (2018: 11) further argues as follows: Given that we are equipped with the capacity to sympathize with others, nothing can prevent the circle of sympathy from expanding from the family and tribe to embrace all of humankind, 
particularly as reason goads us into realizing that there can be nothing uniquely deserving about ourselves or any of the groups to which we belong. We are forced into cosmopolitanism: accepting our citizenship in the world.Therefore, adhering to Pinker's rationale, it appears that the circle of sympathy is a key to understanding our human progress.

Other scholars also support this emphasis on sympathy and compassion. As one of the most well-known scholars in the field of leadership, Cain (2016) has given a record-breaking TED Talk which has been viewed more than twelve million times. In her book (Cain, 2012), she argues that introverted people can make a significant contribution to society. The key concept supporting her hypothesis appears to be sympathy, or, as she states, "a sense to feel close to others emotionally."

Another scholar, Waal (2009), a well-known primatologist, emphasizes (Waal, 2009: 1) that empathy is the grand theme of our time. He points out that even a politician realized this theme and cites the following statement from Barack Obama: "I think that we should talk more about our empathy deficit.... It's only when you hitch your wagon to something larger than yourself that you will realize your true potential." In Waal's The Age of Empathy(Waal 2009), he also suggests that human nature offers a helping hand in this empathy endeavor and that the concept of something emotional or spiritual, rather than pragmaticor physical, is a key to understanding who we areand where we are going in the future.

In addition to Pinker's (2018) and others' propositions dealing with sympathy and compassion, various scholars have theorized about the effect of positive emotions. According to Lazarus (1991), positive emotions are discrete emotions that are positively valencedand that result from benefits rather than harms. These emotions(e.g. hope, joy, contentment, pride, love, etc.) also include a sentiment of elevation, usually leading people to act. For example, Haidt (2003) describes such elevation as an emotional response to witnessing an act of virtue. That response may, in turn, encourage people to affiliate with and help others (Algoe andHaidt 2009). Other scholars have posited that hope is when individuals believe something positive will happen in their lives, even when something positive does not currently exist (Lazarus 1999); and positive emotions can increase individual and societal well-being (Frederickson 2001). Therefore, based on the above theories and assumptions, we may propose that positive emotions displayed in public language, such as a newspaper and/or advertising posters, may have the potential for exerting a substantial influence on the psychological well-being of persons involved in a natural disaster.

Still, the role of positive emotions and compassion may conflict with the traditional principle of journalistic objectivity. Objectivity is the ideal that journalists are unbiased, keeping their values and beliefs out of their work. This definition, therefore, leaves no room for compassion or sympathy. Acknowledging emotions and allowing emotions into a news story is not compatible with the principle of objectivity. However, in today's changing media environment, the principle of objectivity has been questioned. While some might say that emotions are at odds with journalism, there are many who agree that having empathy, compassion and solidarity toward the people is considered an integral part of the journalists' mission. For example, constructive journalism, which draws on insights from positive psychology, argues for the positive role of compassion in journalism (Gyldensted 2015, McIntyre 2015). Hayashi (2011), a Japanese researcher on journalism, argues for what she calls "journalism of care" which emphasizes the connection between journalists and the people being covered by the news (see also Terashima 2005,Fujita 2012, Kingstone 2012, Niwa 2013, Hall and Suzuki 2016).

In this article, we study positive emotions, compassionand sympathy from the journalistic viewpoint ofa local newspaper during the post-disaster period of the Eastern Japan Great Earthquake. In particular, we examine a community project led by the local newspaper, KahokuShinpō, to create and display commercial postersin the city of Onagawa three years after the disaster. People in the city were hit hard by the quake and tsunami, and suffered great loss as a result of the disaster.Owing to perhaps language barriers and difficulties in obtaining access to the research materials, no prior research focusingon alinguistic analysis of the public language in the disaster-stricken area has been conducted. Thus, the present study is the first attempt to examine how positive emotions were expressed in public language, in particular, public commercial postersin the area and how effective they were in empowering the people during the post-disaster period.

\section{Method}

Through site visits to the northeast region of Japan (Ishinomaki, Onagawa and Sendai), we have collected relevant data about the poster project administered by KahokuShinpō newspaper in March and June of 2015 as well as in June of 2017.The poster project itself was run from February 21 to May 31 of 2015. In June 2015, people in Onagawa as well as people from all over Japan, voted onlinefor their favorite commercial poster. Digital photos of the 50 commercialposters, displayed in various stores, were taken for later analysis. In addition, interviews with newspapereditors and reportersat the headquarters of KahokuShinpōwere conducted to gather information about their 
editorial stance, disaster reporting and future perspectives as journalists. Furthermore, local residents were also interviewed regarding their general responses to the posters. The interviews were conducted by the author in an informal, open-ended format so that the interviewees' frank and honest responses could be solicited. In particular, it was noted that disaster victims are generally reluctant to express their personal feelings and experiences to outsiders (e.g., Curtis 2012). Commonly, if approached by a complete stranger, potential interviewees reply that they do not have any comment and turn away. Even if they do engage in conversation, their replies tend to be short and guarded. Thus, extra caution was taken to ensure that the interviewees felt comfortable enough to speak freely with the author. Altogether, 60people volunteered to be interviewed at locations including temporary shopping centers, community centers, and temporary shelter meeting rooms.

\section{Onagawa Posters Project}

The city of Onagawais one of the major port towns in the Miyagi prefecture and has about 6,000 residents. About $90 \%$ of the houses were damaged and $70 \%$ of them were completely destroyedwhen the quake sent a wave almost fifty feet high through thecity. In particular, the fishing port, storefronts, shopping arcades and most commercial buildings all over the city were destroyed by the earthquake and tsunami. The disaster brought sudden attention to Onagawa, and to other towns and cities along the same coastline in theMiyagi prefecture. In Onagawa city itself, it has been reported that approximately 6,000 people were evacuated; however, more than two hundred and fifty people are still reported as missing.

In 2014, three years after the disaster occurred, in an effort to extend support for the survivors of the disaster and to increase public participation, the local newspaper, KahokuShinpō, initiated a civic movement project titled 'Imawatashitachinidekirukoto' (what we can do now). Even though the newspaper has a circulation of about 450,000 and is considered as one of the major newspapers in the region, it is still viewed as a local newspaper by Japanese standards. During the post-disaster period, various media campaigns were conducted (Fukuda 2012); however, unlike the large-scale campaigns, the KahokuShinpōproject was completelylocal -- addressed to the local community by the local media.

In the city of Onagawa, the project was designed to help small shop owners stay in business. Although almost four years had passed since the disaster, the rebuilding process had beenvery slow and the majority of small businesseswere housed at temporary shopping centers. The project's objective was to produce several advertising posters for each store in order to publicize their business.I interviewed editors, including Mr. Koji Ishii atKahokuShinpō,regarding the content of the poster project. One of the astonishing purposes for their project was to encourage and stimulate public participation in the recovery efforts in and outside of their newsroom. They felt especially strong that stimulating communityparticipationwasafundamental key to the successful recovery of the area.In other words, not just staying in the newsroom and producing their usual, regular newspaper, but actively going outside the newsroom and beinga part of the community effort, they felt, was crucial to their recovery project. Their rationale was that the poster project was not just a passive effort by their newspaper, rather it required them to play an activepart in the recovery process themselves, including locating poster professionals, running the logistics of the various events, and organizing the efforts on a local as well as national level. For example, their decision to use actual images on the commercial posters, rather than abstract propositions, showed their commitment to the local community and proved more convincing and more memorable. Telling a story using commercial posters, itself, was evidence of the participatory strategy which encouraged people to be an active part of the recovery efforts.

About 60 photographers and copy writers volunteered and 42 small shops and businesses participated in the project.The posters for each store were displayed at the store's entrance. Compilations of posters were also displayed on bulletin boards posted at several temporary shopping centers and at public places such as the train station. As the photographers, copy writers and journalists contributed to the project, they too became participants, rather than spectators.

\section{Encouraging positive emotions}

A surprising feature of the commercial posters is their cheerful, bright and often humorous depictions, usually generating positive emotions in their viewers. Their cheeriness is unexpected against the backdrop of the disaster's damage still evident everywhere in the city and region. Some organizers of the project worried that it might be inappropriate to produce and display the amusing posters in light of the hardships suffered by the survivors and residents of the community. They reasoned that such posters may be socially and culturally insensitive to the local people. However, contrary to their initial concerns, the posters were well received. 
They offered the residentsa chance to refocus, relax and refresh, even for a brief period of time. In interviews, manyresidents responded that they really needed these cheerful moments when they could look forward to the future, rather than dwelling on the memory of the disaster. See below the poster at a vegetable shop.

Photo 1: The vegetable shop owner and posters atan entrance to the shop

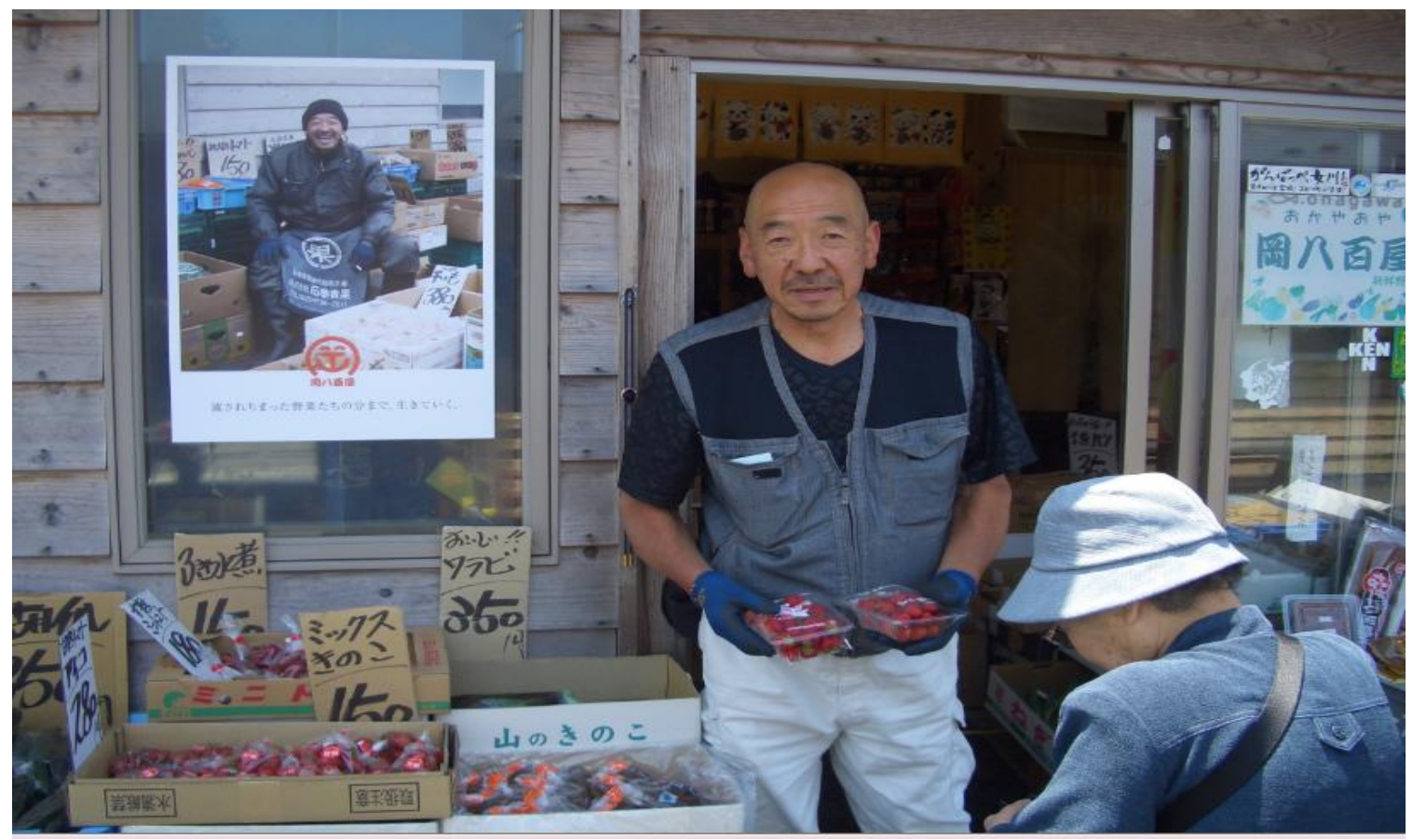

The shop owner is holding containers of strawberries for a customer. In the poster behind him, the same owner is smiling and the caption reads that'Nagasaretayasai no bun made ikiteiku'(I will live for the vegetables washed away by the tsunami). The poster's message shows that the owner is committed and will push forward and survive, even for the sake of the vegetables he sells. It is a reminder for himself but also for the hard-working people who visit his shop. The message is very positive and encouraging. Next, observe the poster for a flower shop.

Photo 2: Poster for the flower shop

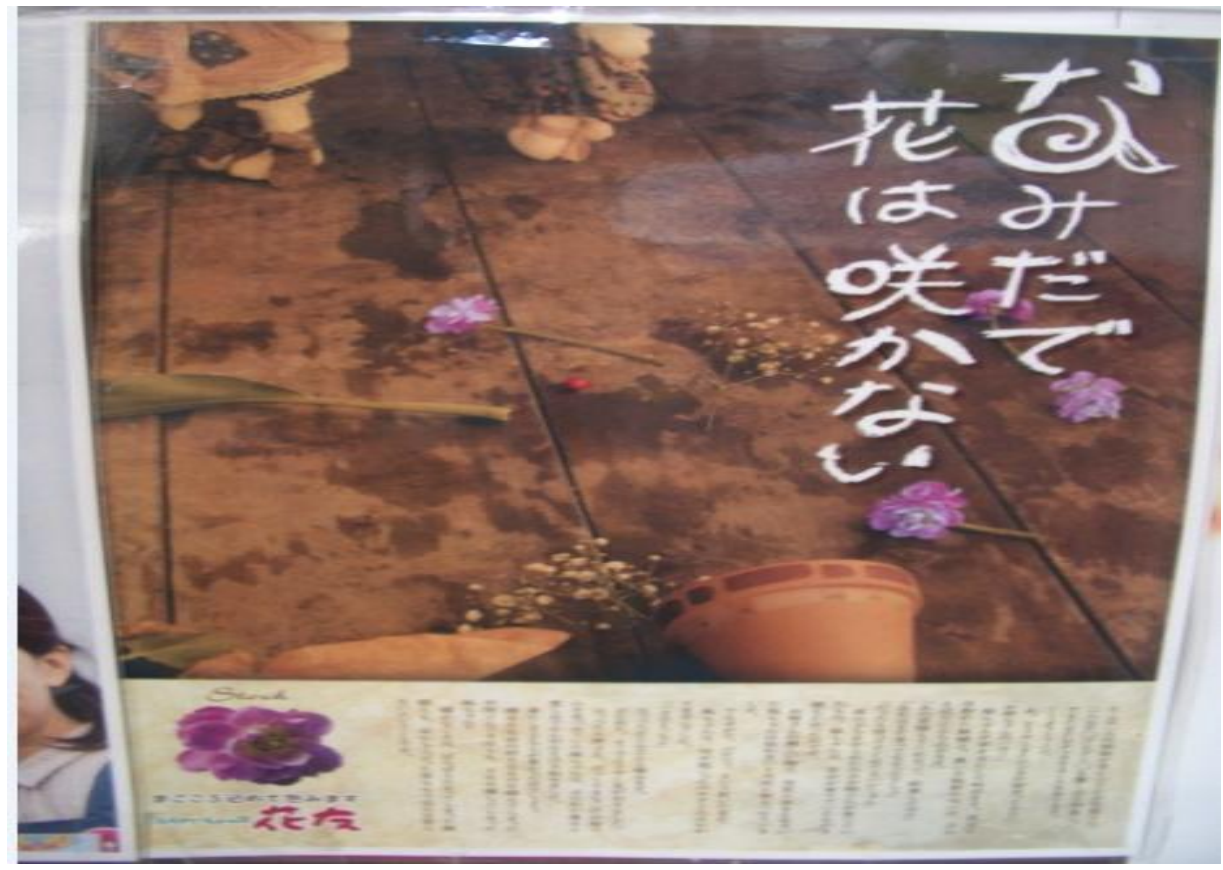

The caption says that 'Namida de hanawasakanai' (Flowers do not bloom with tears). The poster conveys the message that crying over what happened in the disaster does not bring a solution or desirable outcome. It encourages people to look forward. 
The following photo 3 shows an electronics store owner and a poster behind her. The poster for the electronics shop is shown in photo 4.

\section{Photo 3: The electronics shop owner}

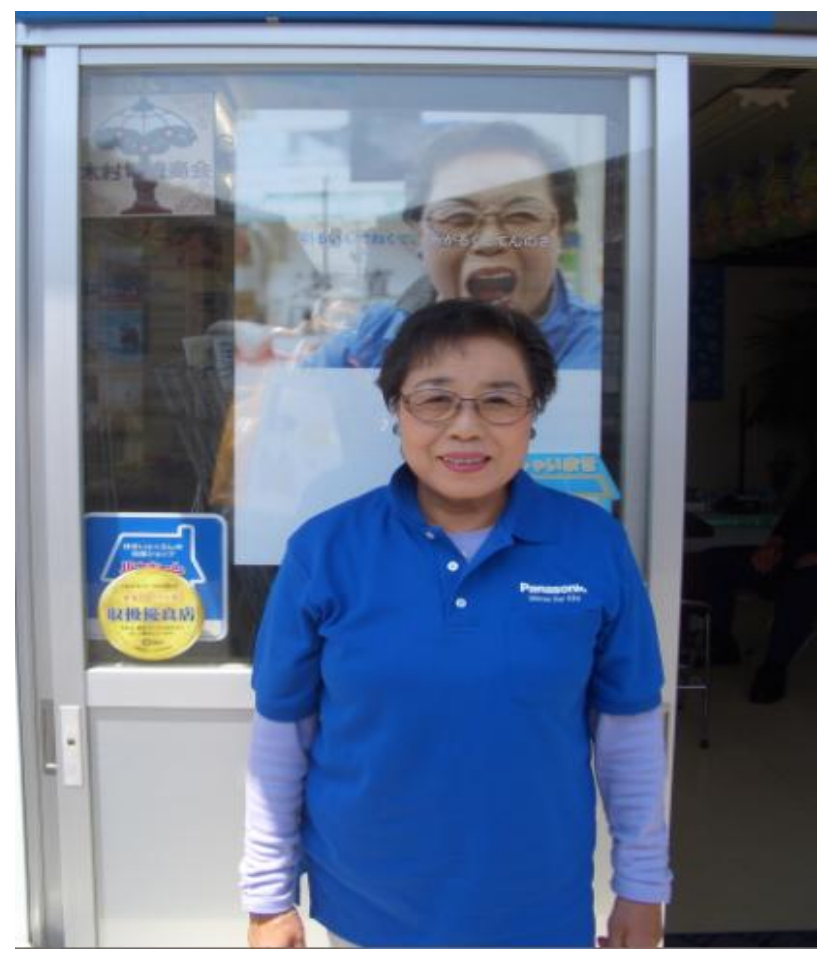

The shop owner smiles in front of her shop in photo 3. But in the poster in photo 4, she appears to be screaming something. The caption reads'Akaruin de nekute, agarukushitennosa' (I am not naturally cheerful but I am deliberately trying to be cheerful). It is a humorous expression of her determination to be a cheerful person. This poster sends the message that even when we feel discouraged or depressed, we can try to encourage ourselves to be cheerful, vigorous and energetic as much as possible. Note also that the designers of the poster used the regional dialect expression of agaruku (instead of akaruku), communicating a sense of familiarity and solidarity with the local residents.

Photo 4: The poster for the electronics shop

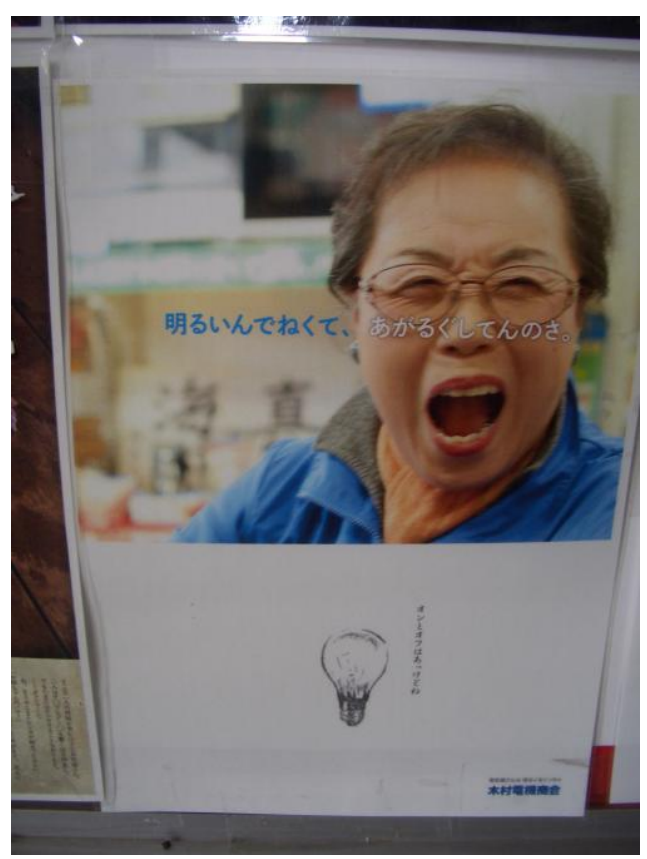




\section{Avoiding the post-disaster frame or negative emotions}

The photos we have examined so far are designed to deliberately send an overt encouraging message. The message is providedin the frame of the disaster and inspires residents to be successful survivors of the disaster. Nevertheless, although these posters are well-intended, the posters themselves evoke memories of the disaster and its devastation. In other words, when looking at these posters, viewers cannot avoid being reminded of the quake and tsunami due to the poster's frame.By contrast, there are other posters which do not provoke images and memories of the disaster at all. They are free from the post-disaster frame. Observe the following poster for a green tea shop.

Photo 5: The poster for the green tea shop

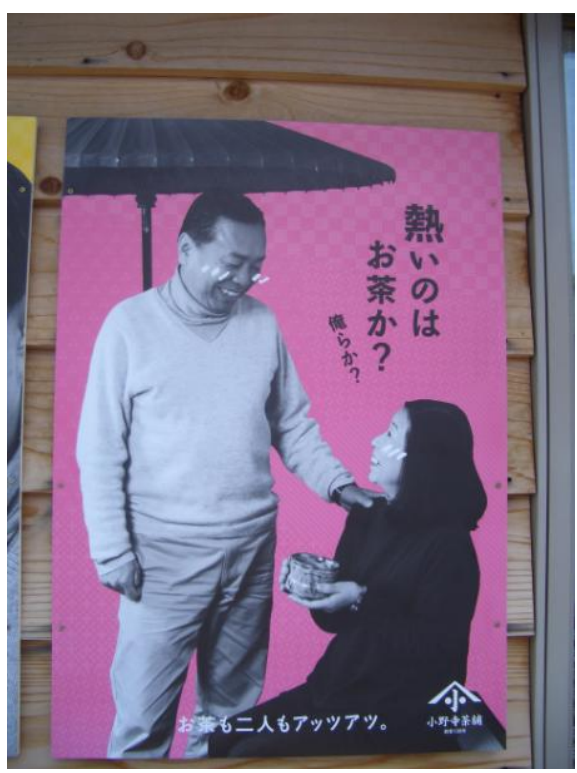

The middle-aged couple, who happen to be the shop owners, appear in the poster together. The husband asks his wife, who holds a cup of hot tea 'Atsuino waochaka? Oreraka?' (Is it the tea or us that is hot?).The word atsui belongs to two semantic fields ("bisociation" in Koester 1964); the temperature of the tea is hot, and the relationship of the couple is hot. There is no hint of the disaster or negative emotions, and the poster simply depicts the middle-aged couple to still be in love like they were when they were younger. The conversation along with the picture triggers smiles for many viewing the poster. It gives a sense of relief, adds humor and reminds of their own happy occasions in life (Solnit 2009).

Note the next poster which is an advertisement for akushiyaki(grilled food on skewers) diner.

Photo 6: The poster for the kushiyaki diner

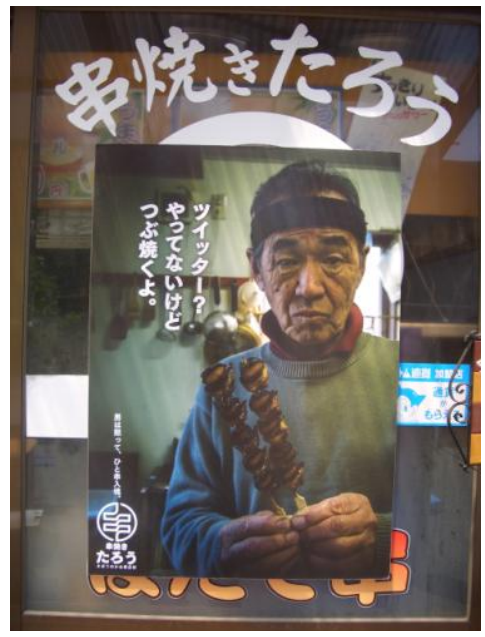


The owner of the restaurant holds two pieces of skewered sea food he just grilled for a customer. The caption says 'Tsuittā? Yattenaikedotsubuyakuyo' (Twitter? I do not do it, but I tweet the food). To tweet is tsubuyaku in Japanese, but tsubu oftsubuyaku has another meaning, that is 'whelk,'and yaku of tsubuyaku means to 'grill.' The pun is taking advantage of the two homophones of the wordtsubuyaku, one is to tweet and the other is to grill the whelk. The owner of the diner appears old fashioned and is occupied only by grilling sea snail. He certainly stays away from trendy communication technology and yet, he seems very proud of what he does in his own way. The pun itself provides an amusing moment for viewers but also the poster sends a clear message about the restaurant owner's commitment to his profession. In turn, people will likely perceive his underlying strong determinationto focus on his work without being bothered by outside influences. Incidentally, the poster was voted as the best poster in the election survey of all posters at the end of the event.

The following poster goes beyond a depiction of everyday life like the ones we have observed so far. It is rather drastic and even has some sexual connotation. The poster is for a curry restaurant.

Photo 7: The poster for the curry restaurant

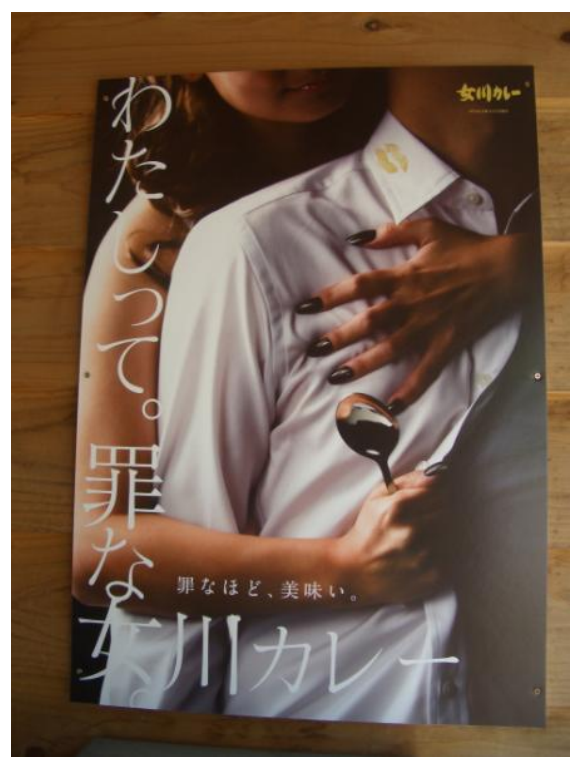

A woman, who is supposed to be the owner of the restaurant, holds a man in a white shirt from behind. The collar of the white shirt has a mark of yellow lips (apparently from the woman's curry-smothered lips). The image appears to communicate that the man is literallycaptured (or even seduced) by the woman and her curry because the curry is so delicious (the woman is so attractive). The vertical line says 'Watashittetsuminaonna' (What a guilty woman I am!) and the horizontal line says 'Onagawakarē' (Onagawa curry). The vertical and horizontal text lines intersect at the point where they share the word onna. One meaning of onna is woman; the other meaning relates to the Onagawa brand name for the curry.Combined, it is a portmanteau sentence using onna as a transitional bridge. The poster appears provocative because of the sexual connotation. Because the viewers of the poster are local residents who have experienced the traumatizing disaster, one may think that the poster could be inappropriate on moral, social and emotional grounds. In particular, the national mood of self-restraint or "jishuku" (Hendry 2014) in sympathy with the victims might make people stay away from any openly entertaining picture. However, based on the research, no one in the community had complained about the poster and, in fact, the poster was one of the most popular posters in the series (KahokuShinpō 2015).

The findings from numerous interviews showed that the posters evoked positive emotions and people, in general, appreciated and were ready to accept their light-hearted approach. One of the viewers stated that she was impressed by the cheerful, funny and appealing tone of the posters. This kind of feedback was shared by the great majority of the viewers.As a result of their popularity, the newspaper created an informal voting event, imitating a political general election, in which people voted for their favorite posters.According to the KahokuShinpō, more than 15,000 people participated in the voting. Given that the entire population of Onagawa is merely 6,000, the large number of voters reflected the enthusiasm for the event and the support of many people across the country of Japan (KahokuShinpō 2015). 


\section{Discussion - Is there a place for sympathy and compassion in journalism?}

The mission of journalism is to inform and reflect, as accurately as possible, the community that it serves (Harland 2008). Accuracy and truth telling are paramount and the principle of "objectivity" has long been an ideal for journalism. However, this principle of objectivity often leads to a hyper-focus on negative and conflict-based information. When we read newspapers or watch TV news channels, we typically find news such as crime, violence and war. A common assumption may be that journalists gravitate toward drama, deviance and scandal. According to a national survey in Patterson (2000), 84\% of respondents perceived the news to be depressing and only $16 \%$ of them reported that the news wasspiritually uplifting (cited in McIntyre 2015).A stereotypical image we may also paint of journalists may include belligerent, stubborn, and disrespectful personality traits, but certainly not the attribute of compassion (Harland 2008, see also Pinker 2018).

Nevertheless, as this study has shown, compassion may actually be an attribute that helps journalists understand and connect with the people they serve. The notion of civic journalism (e.g., Rosen1999) becomes very revealing when journalists are forced to deal with the aftermath of a catastrophic disaster such as the Japanese earthquake and tsunami. In the case of the Onagawa poster project, initiated and organized by the regional newspaperKahokuShinpō, the paper went beyond its expected role of just publishing the news. Its journalistsleft the comfort of their newsroom, went into the community and, with the help of volunteers, coordinated the creation of a posters project.In particular, the posters they created were designed to trigger positive emotions, and even humor as discussed in the previous section. Humor is generally considered an effective tool to cope with tragedies (e.g., Keltner andBonanno 1997,Martin 2007,Strick, Holland, van Baaren, and van Knippenberg 2009,Kimura2010). The humorous posters were successful in distancing the people from the harsh realities of the disaster and facilitating effective coping strategies among community members.

Another interesting feature of the Onagawa project is the fact that it energized not just the local community, businesses and the residents alike, but also the people outside the regions affected by the disaster. A large number of people traveled to Onagawa to view the posters and to interact with shop owners and the local people.The journalists' compassion enabled them to encourage the civic engagement.In his theory of public journalism, Rosen (1999: 54) argues for an approach that can "address people as citizens, potential participants in public affairs, rather than victims and spectators."'Indeed, the Onagawa project allowed local Onagawa residents to become participants, rather than mere victims, and people from outside the region to become spectators, rather than people who would not likely have participated at all. The project was a social experiment, but it generated a movement which encouraged public participation.

The idea of public participation and involvement has been widely discussed by Tannen (2007), who has examined "small talk" among other sociolinguistic phenomena. According to her, conversational discourse exists not merely to convince audiences, but also to move them emotionally. In other words, mutual understanding is facilitated, or even enabled by an emotional experience of interpersonal involvement. This involvement is an internal or even emotional connection individuals feel which binds them to other people as well as to places, things, activities, ideas, memories and words. If we follow Bakhtin's (1975) notions, we can say that all language use, including commercial posters, is dialogic, or,it is a "joint production" between a speaker and an addressee. To put this differently, we can say that ideas or senses can be conveyed/articulated through the creation of a shared world of images between people. In this sense, the posters at the Onagawa project are an excellent example of this idea of mutual involvement between poster creators, shop owners, and viewers. Participants experienced a kind of "mutual participation" in sense making. The posters indeed proved to be"dialogic," like any other kind of language use.

\section{Conclusion}

Rosen (1999: 54) has described the following general characteristics of journalists: "Journalists tend to see themselves as observers; their job is to tell the truth, not to bring new truths into being. Almost all the key tenets in their ethical code emphasize detachment rather than participation."'Thus, we might ask, is there a place for journalist involvement and participation in news reporting and, if so, how much? What is the ideal relationship between detachment and participation? Surely, it is difficult to draw a clear line. It may bemore of a grey area where multiple factors must be considered. Uchida and others (Uchida, Kanagawa, Takenishi, Harada, Okawa and Yabuno 2015) have examined the relationship between objectivity and emotionality in Japanese media coverage with respect to the earthquake and tsunami. One of their findings is that journalists' orientations tended to be more objective than emotional. However, they also pointed out that one of the features of Japanese media is emotionality and argues that "emotionality in Japan is related to the 'culture of sympathy,' a bonding tool that is used to achieve interdependence between people. Sharing emotional status with others is perceived as important to understanding others." They argue that emotionality continues to be an integral part of the media coverage in Japan. 
The present study suggests that exercising journalistic compassion during the recovery period of a natural disaster can be an effective and valued contribution by local newspapers. Doing so is a productive way of connecting and reconnecting with the residentsurvivors and identifying, addressing and supporting their needs. To this end, the newspapers' decision to focus on positive emotions resulted in reducing burdens of sorrow and despair and providing hope for the people. Compassion as participants, not objectivity as observers, has earned the journalists at the local newspaper,KahokuShinpō, trust from the Onagawa community, now and into the future.

In conclusion, the following is an excerpt from anOnagawa resident's letter sent to the editorial office of the KahokuShinpō. While speaking of the newspaper in general, it readily applies to theOnagawaposters project.

"I found out that the sight in front of me is now very bright and shining. This is because I really feel now that I have emotionally connected with reporters who write articles, people who print the newspaper and people who deliver the newspaper to us. I used to think that running a newspaper meant delivering news and nothing more than that. However, I now feel that this is not true. Instead, I have realized that running a newspaperactually consists of encouragement, sympathy, and the offering ofopinions from various viewpoints. Now, I realize that your newspaper is a 'giftto me which is delivered every morning." (KahokuShinpō 2011: 56-57).

\section{Acknowledgement:}

I am grateful to Mr. Kōji Ishii of KahokuShinpōand Mr. Eiichi Hiratsuka of the Onagawa city government and the people in the disaster-stricken area for allowing me to interview them.A part of this research was funded by a Japanese Grants-in Aid for Scientific Research (2014-2016).

\section{References:}

Algoe, S, andJ.Haidt. 2009. Witnessing excellence in action: The "Other-Praising" emotions of elevation, gratitude, and admiration. The Journal of Positive Psychology 4(2): 105-127.

Bakhtin, M. M. 1975. The dialogic imagination. Austin: The University of Texas Press.

Cain, S. 2012. Quiet: The power of introverts in a world that can't stop talking. Crown Publishing Group.

Cain, S. 2016. Quiet Power: The secret strengths of introverts. New York: Dial Books for Young Readers.

Curtis, G. 2012. Tōhoku diary: Reportage on the Tōhoku disaster. Natural Disaster and Nuclear Crisis in Japan: Response and Recovery after Japan's 3/11, ed. by J. Kingston, 15-32. New York: Routledge.

Fujita, M. 2012. Higashi nihondaishinsaihōdō no kenshō. Mass Communication Kenkyū, 81, 17-19.

Fukkōchō. 2017. Zenkoku no hinanshatō no sū. http://www.reconstruction.go.jp/topics/main-cat2/sub-cat21/20170328_hinansha_suii.pdf.

Fukuda, M. 2012. Daishinsai to media: Higashi nihondaishisai no kyōkun. Tokyo: Hokujushuppan.

Fredrickson, B. L. 2001. The role of positive emotions in positive psychology: The broaden-and-build theory of positive emotions. American Psychologists, 56(3): 218-226.

Gyldensted, C. 2015. From mirrors to movers: Five elements of positive psychology in constructive journalism. GGroup Publishing.

Haidt, J. 2003. Elevation and the positive psychology of morality.Flourishing: positive psychology and the life welllived, ed. by C. L. M. Keyes and J.Haidt,275-289. Washington, DC: American Psychological Association.

Hall, J. M., andM. Suzuki. 2016. The role of volunteering in post-tsunami town recovery. Japan After 3/11: Global perspectives on the earthquake, tsunami, and Fukushima meltdown, ed. by Karan. P. Pradyumna and U. Suganuma, 364-378. Lexington, Kentucky: The University Press of Kentucky.

Harland, K. 2008. Practicing compassion in an unbiased journalism. http://ethics.journalism.wisc.edu/2008/06/16/practicing-compassion-in-an-unbiased-journalism/.

Hayashi, K. 2011. Onnakodomo no jānarizumu. Tokyo: Iwanami Shoten.

Hendry, J. 2014. Learning that emerges in times of trouble. When the Tsunami came to shore, ed. by R.Starrs, 166-178. Boston: Global Oriental.

KahokuShinpō. 2011. KahokuShinpō no ichiban nagai hi. Tokyo: BungeiShunjū-sha.

KahokuShinpō. 2015. Onagawaposutā ten sōsenkyokekkahappyō.http://www.kahoku.co.jp/imadeki/2014/paper12.html.

Keltner, D. and G. A. Bonanno. 1997. A study of laughter and dissociation: Distinct correlates of laughter and smiling during bereavement. Journal of Personality and Social Psychology, 73(4): 687-7-2.

Kimura, Y. 2010. Warai no tōitsuriron. Warai o kagakusuru, ed. by Y. Kimura, 1-22. Tokyo: Shinyōsha.

Kingstone, J. 2012. Natural disaster and nuclear crisis in Japan: Response and recovery after Japan's 3/11. New York: Routledge. 
Koester, A. 1964. The act of creation. London: Hutchinson \& Co.

Lazarus, R.S. 1991. Progress on a cognitive-motivational-relative theory of emotion. American Psychologist, 46(8): 819-834.

Lazarus, R.S. 1999. Hope: An emotion and a vital coping resource against despair. Social Research, 66(2): 655-678.

Martin, R. A. 2007. The psychology of humor: An integrated approach. Boston: Elsevier.

McIntyre, K. E. 2015. Constructive journalism: The effects of positive emotions and solution information in news stories. Ph.D. diss., University of North Carolina at Chapel Hill.

Niwa, Y. 2013. Higashi nihondaishinsai o kiokusuru. Media gafurueta: Terebi, rajio to higashinihondaishinsai, ed. by Y.Niwa andM. Fujita, 359-400. Tokyo: Tokyo DaigakuShuppankai.

Patterson, T.E. 2000. Doing well and doing good: How soft news and critical journalism are shrinking the news audience and weakening democracy - and what news outlets can do about it.MA: Joan Shorenstein Center on the Press, Politics and Public Policy, Harvard University.

Pinker, S. 2018. Enlightenment now. New York: Viking.

Roser, M. 2016. Natural catastrophes. Our world in data. https:/ourworldindata.org/natural-catastrophes/.

Rosen, J. 1999. What are journalists for? New Haven: Yale University Press.

Solnit, R. 2009. A paradise built in hell: The extraordinary communities that arise in disaster. New York: Penguin.

Strick, M, RW. Holland, R. B. van Baaren, andA. van Knippenberg. 2009. Finding comfort in a joke: Consolatory effects of humor through cognitive distraction. Emotion 9(4): 574-578.

Tannen, D. 2007. Talking voices. Cambridge: Cambridge Univesity Press.

Terashima, H. 2005. Shibikkujānarizumu no chōsen. Tokyo: Nihon Hyōronsha.

Thorson, E. 2012. The quality of disaster news: Frames, disaster stages, and a public health focus. Reporting disaster on deadline, ed.by M. Steffens, L.Wikins, F.Vultee, E.Thorson, G. Kyle, andK. Collins, 69-89. New York: Routlege.

Uchida, Y, C. Kanagawa, A. Takenishi, A. Harada, K. Okawa, and H. Yabuno. 2015. How did the media report on the Great East Japan Earthquake? Objectivity and emotionality seeking in Japanese media coverage. PLoS ONE Vol. 10(5), https://www.ncbi.nlm.nih.gov/pmc/articles/PMC4436106/?report=reader

Waal, F. de. 2009. The age of empathy: Nature's lessons for a kinder society. New York: Three Rivers Press. 